\title{
The Historical Evolution of China's Modern Outbound Tourism
}

\author{
Zhihui Li \\ Department tourism and hotel management \\ Pingdingshan Institute of Education \\ Pingdingshan, Henan, China 467000
}

\begin{abstract}
Tourism, as an important symbol of productivity, its development to a certain extent reflects the society as a whole. Modern Chinese outbound tourism development is closely related to the social and historical background, mainly involving the literati, intellectuals, students, and three kinds of main body of government officials, the three kinds of main tourist activity, is the modern Chinese outbound tourism development history, the premise of accurate textual research today is in the process of developing tourism draw lessons from the basis of their experience.
\end{abstract}

Keywords—outbound tourism; history; research

\section{INTRODUCTION}

Tourism is people to leisure, entertainment, visiting friends or business purposes, to other places for not employment, not living purpose visit or temporarily stop the sum of all kinds of phenomena and relationships. ${ }^{[126}$ As an important aspect of economic development, the outbound tourism in China's modern history also has a certain development. After the opium war, China closed state began to be broken, gradually reduced to a semi-colonial and semifeudal society, and then brings the change of the social each domain, modern Chinese outbound tourism began to rise. Textual research to the outbound tourism development status in modern history, is the key to the accurate positioning its historical significance.

\section{THE HISTORICAL BACKGROUND OF THE}

\section{DEVELOPMENT OF MODERN CHINESE OUTBOUND TOURISM}

The emergence and development of outbound tourism in modern China, is the result of the social productivity improvement, and at that time, China is closely related to the historical background, is the industrial revolution, the change of political environment, economic structure change the result of joint action of many factors.

\section{A. The influence of the industrial revolution}

In the $1760 \mathrm{~s}$, Britain in the first industrial revolution, gradually substitute capitalism machine production workshop handicraft industry. Soon after, the first industrial revolution gradually spread in major capitalist countries such as Germany, to the middle of the 19th century, major capitalist countries has been completed for the first time the industrial revolution. After the opium war, with the invasion of western capitalism, objectively promoted the development of China's national capitalism economy, machine production began to appear in our country, the social wealth increase rapidly, this objectively provides material conditions for our country modern travel abroad. National capitalist economic development at the same time of increasing wealth, also brings to our country social class change, emerging national bourgeoisie, breaking the traditional social wealth by the feudal aristocracy a class and centralized control of the situation, the bourgeoisie began to grasp a large number of social wealth, which also make it possible to travel abroad popular, has also changed the outbound tourism subject simplification. Not only that, the industrial revolution is to promote the development of modern traffic. Traffic is one of the tourism spatial shift in the basic passenger transportation facilities and equipment, the ancient traffic behind makes people distance difficult cross-border tourism, people travel in the space distance. But after the industrial revolution, powered by steam of new traffic tools such as cars, trains, not only shorten the people travel time, also for people to realize long-distance travel abroad to create a good transportation conditions.

\section{B. The changes of the political environment}

Before the opium war, modern China is a highly centralized feudal state, self-sufficient economy dominates, the so-called "China powder products, offering the original not by foreign goods to have" [2]425 so few foreign communication activities. In late Qing Dynasty, in order to prevent the encroachment of foreign powers, the Qing government is implementing the "isolation" policy, Chinese and foreign exchange basic cut off. After the opium war, along with our country modern times the first unequal treaty signed the treaty of Nanjing, a variety of trading ports are forced to open, closed the gate began to open in China. These unequal treaties signed, makes the modern China was gradually reduced to a semi-colonial and semi-feudal society. Severe national crisis prompted a man of insight to focused on abroad, a large number of advanced intellectuals at this point it is through the way of outbound tourism, to go abroad to study on the development of the foreign advanced experience, explore the new ways of saving the nation from subjugation. 


\section{The change of the economic structure}

As a traditional agricultural society, "the farmer" suppression policy has been used by all previous dynasties rulers, in the feudal society for a long period of time to promote the development of the economy. But as the bud of modern capitalism, commodity economy development, "the farmer" suppression policy has serious is not adapt to the development of economy. Westernization movement in the 1860 s, with "self-renewal", "rich" as the goal, at that time the Chinese government also issued a series of laws to promote the development of economy and the establishment of some industries, in order to realize the development of industry and commerce, then, a large number of industry get fast development, only seven years from 1912 to 1919 , China's new industrial and mining enterprises amounted to more than 470, investment of nearly 100 million Yuan, plus the original enterprise expansion, the capital of 130 million Yuan. ${ }^{[3] 473}$

With the deepening of the economic structure change, the self-sufficient natural economy began to collapse, instead, the rapid development of commodity economy, the development of commodity economy inevitably has prompted the Chinese and foreign exchange activities increased, a large number of Chinese people began to use the opportunity to travel abroad to engage in international trade. In this sense, the economic structure change is China's modern tourism and the development important condition.

\section{THE MODERn CHINESE OUTBOUND TOURISM SUBJECT CLASSIFICATION}

Before the rise of mass tourism in the $1920 \mathrm{~s}$, the main body of China's outbound tourism activities is limited to the feudal government officials, but as China's international gradually is opened, the influx of western ideology and culture, the traditional concept of ideology and culture, intellectuals, students, some scholars also began to participate in outbound tourism, make the main body of modern Chinese outbound tourism activity presents a diversification characteristic.

1) Civilian intellectuals. Advanced civilian intellectuals is one of the early practice group of modern Chinese outbound tourism, and in many intellectuals, Lin needle is the pioneer of modern advocates the overseas travel. In 1847, Lin needle is proficient in foreign languages and translation was hired as the United States, thus obtained to living in a year in the United States. Returning home, he will travel in the United States through detailed records, and recorded in the book record articles of west sea grass, become "modern Chinese used to measure the external world the first shell of the sea" ${ }^{[4] 12}$. Since then, the modern Chinese people use the book as an important window to the outside world. Overseas travel life a year, also enriched the life experience of Lin, widen their view, so that the needle Lin also larger change in ideology. Early after needle Lin, and outbound tourism an important representative of intellectuals. In 1854, Rosen followed m. c. Perry (m. c. Perry is in the east India admiral) fleet to Japan for tourism activities, on the road of 7 months, Rosen details the Ryukyu region's cultural customs, at the end of the journey, he will know about Japanese politics, economy, culture and so on various aspects condition collection book "Japan's diary", this is the modern Chinese people's first recorded about Japan's experiences, to know the experience of Japan's development has important value. Besides Lin needle and Rosen, the literati Wang Tao is also a strong advocate of outbound tourism, intellectuals in the alkali and Luo Sen round trip to the United States after the completion of the trip to Japan Wang Tao began a trip to Europe, lasted more than two years, then at the invitation of the Japanese friends treat "digest luggage sent tour", its outbound tourism experience is very rich, finally complete the roaming with record and hula "two wonders of the book, for the modern people to understand the status of the European and Japanese society has a certain reference value. As early modern travel abroad the first batch of civilian intellectuals, needle, Rosen, Wang Tao Lin has opened the prelude to travel abroad in modern China, with 1876, the Qing government formally sent resident foreign minister, civilian intellectuals began to peaking to travel abroad, leaves later generations lots of books introduce foreign situation, such as "new record" circling the globe of Li GUI, Huang Qingcheng east travel diary, money "Guimo luxing ji shan shili and journey" to record ", these are the precious historical literati outbound tourism in China's modern history.

2) Students. Students in modern Chinese outbound tourism is the largest number of groups, they travel abroad is mainly affected by the social "long skill with barbarians" ideological trend influence, to travel abroad at the same time study, to learn advanced western science and technology. In many students, Yung wing is the pioneer of open overseas study tour in modem history of our country. Yung wing, ancestral home in Xiangshan, Guangdong province, childhood poorer, Blanc couples to create the Morrison school in 1841. Blanc in his return from illness, in 1847 , Rong hong from Guangzhou to the United States, with Huang kuan, Huang sheng formally started to study the history of the United States. Yung graduated from Yale university in 1854, becoming the first in the history of our country to graduate from the university of the United States, a Chinese student, Yung oneself from discussing the matter also said: "in Chinese and graduated from the United States first big schools, solid from the beginning to" ${ }^{[5] 88}$. Began in 1872, the government official to send students to travel around the world study, represented by Zhan Tianyou the first batch of 20 young students in August 1872 to be sent to the United States to study, and this work is the recruitment of 20 young children in the charge of Yung wing. Due to a long period of isolation, when a lot of people don't understand the government the measure, as for the "alien word" travel abroad study. Many traditional aristocratic family, reluctant to children to travel abroad study Yung has 
spent more than a year to fill seats. The tourism authorities sent study work is completed, the domestic tourism culture began to spread abroad study and to the may fourth movement period, has reached more than 40000 people, arrived in main countries of the United Kingdom, the United States, Japan, Germany, the Soviet union and other countries. Although the main purpose of the foreign students go abroad is to learn advanced western science and technology, to achieve the purpose of saving in China, but a massive international students go abroad also inevitably lead to the development of modern Chinese outbound tourism, it objectively is also a huge driving force.

3) The government officials. It should be said that China's outbound tourism development in modem history of government officials is the most important support strength, government officials outbound tourism there are three main forms. A. Foreign tourists. In 1866, Lin Tsubaki and led to pavilion three students, under the guidance of the British Hurd, traveling to Europe, prince Gong Yi letter to the purpose of the visit is to "explore the pros and cons, with a little knowledge, borrow to raise plan", and asked the tour "mountains along the way, will have the situation, local conditions and customs, detailed" [6] 68-69. Abroad, therefore, the foreign tourist group basically belongs to the nature of the tourism, is the Qing government sent outward Tours, from the perspective of the government to understand Europe's basic situation. After the end of the trip to Europe has left some wonders about Europe's diary, such as "by rubbing notes", the navigation above, and so on. In 1868 , the Qing government sent a formal diplomatic tour, organized by Anson Burlingame and led them minister said the mission. Though as a formal diplomatic corps, the qing government and the group of too much to the task, no regulations to this, it is recorded in the "early make Tessie" : "he's good at the right, in I have to accept. If not, even bowed to". If it does not work, but even return ". As a result, the group is also basically belongs to the tourist group, has used more than two years of time traveled in 11 countries such as Britain, the United States, Germany, formed the early make Tessie ", the navigation above and six volumes "again and" make the West JiCheng wonders to remember. B. The second is technology inspection tour.Under the influence of the westernization movement, the Qing government began to realize that must send officials to visit abroad, to grasp the present situation of the development of the western technology. In 1879, the Qing government sent $\mathrm{Xu}$ Jianyin wait for a tour of Europe, unlike previous investigation, the clear the tour groups have important research task of science and technology, and buy armored battleship. In more than 20 months, $\mathrm{Xu}$ Jianyin delegation visited more than 80 small factory, and more than 200 kinds of technique and management method for the detailed records, for our country and western science and technology communication provides a detailed reference material. Meanwhile, on the basis of extensive investigation in France,
Germany, UK shipyard, Xu Jianyin ordered built two German ships, later to Beiyang fleet "far" and "town", known as the best real ship at that time. C. Three is a comprehensive tourism. In Guangxu decade (1884), along with the practice of westernization, the westernization movement realized just send a few people to travel abroad investigation technology, far can not adapt to the learning of foreign needs, therefore, under the urge of westernization movement, the Qing government sent officials to travel abroad investigation has begun. Respectively in 1887, the Qing government sent 12 people travel to Japan and Europe and the United States, this is the first time that the Qing government sent so many officials to go abroad. The expedition just learning foreign science and technology, but also social, economic, cultural and other aspects of content, such as the ministry of war alternate card shark Fu Yunlong after investigation in 11 countries, write "tour around the map 86 volumes, which involves the national official, diplomatic, military, canals, etc.

\section{MODERn CHINESE OUTBOUND TOURISM DEVELOPMENT OF HISTORICAL SIGNIFICANCE}

Since modern times, the western civilization constantly impact on China's traditional civilization, modern Chinese outbound tourism also develop in the process, and starting from the local scale to penetrate social each aspect, social development is of great significance to our country. One is broadened horizons of the people. As the important way of foreign civilizations, outbound tourism has broken the traditional thought of closed situation in our country, further understand people of other countries in the world and create conditions for the formation of modern ideology. The second is speeded up the process of Chinese modernization. In the process of the transformation to modernization in our country, a lot of outbound tourists have played an important role, whether advanced civilian intellectuals, to the student, saving the nation from subjugation and learning western advanced technology of officials, they on the investigation to the abroad, makes the people to realize the gap between China and other countries at that time, only continuously strengthen the social transformation, to the world, for the destruction of the agricultural society, plays an important role to the formation of the industrial society, speeded up the process of Chinese modernization. Three is to create conditions for modern tourism. Modern outbound tourists left a lot of records about travel abroad, from the Angle of different foreign history, geography, and has carried on the profound analysis, these are our current in valuable resources can be drawn lessons from the development of modern tourism.

\section{REFERENCES}

[1] Wang Degang. Introduction to tourism [M]. Publishing house of Shandong university, 1995), page 26.

[2] Wang Xianqian. Donghua continued to record [M]. Chase publishing company, 1984), p. 425.

[3] Li Kan. Modern Chinese history [M]. Zhonghua press, 1994), p. 473. 
[4] Zhong Shuhe. Go to the world series, the west sea grass record articles [M]. Yuelu press, 1985), page 12

[5] Rong Hong. Remember [M]. Introduces Zhongzhou ancient books publishing house, 1998), p. 88

[6] Bin chun. To the world of books, by rubbing notes [M]. Hunan people's publishing house, 1981), pp. 69-68. 